\title{
Public Administration at A Crossroad: Policy on Agricultural Extension within Digital Society
}

\author{
Wahyu Riawanti ${ }^{1}$ \\ Kurnia Cahyaningrum Effendi ${ }^{2}$
}

\begin{abstract}
The study is aimed to reveal the public administration process in a challenging digital society. Facing the globalization, agriculture sector in Indonesia cope with the same challenge. In term of modernization, the role of agricultural extension is considered as one of the main factors in transferring technology and knowledge to the farmers. The case study was taken on Indonesian agriculture policy in Yogyakarta Province to reveal two different aspects namely (a) the dynamic and relevance of agriculture policy to deal with nowadays digital society challenge and (b) how the extension agents respond the policy in terms of digitalized society and globalization. The qualitative data was taken from in-depth interview and FGD with extension agents in Yogyakarta province were used for the research main data. The research result has shown that the impact varied from different extension groups/districts. The characters of extension agents and mostly Indonesian agriculture sectors are mostly the aging agriculture labors and lower technology application. This study results on how the agriculture policy was historically put the entity of extension agents as merely "object of development". This phenomena finally has to cope with recently global agriculture problem.
\end{abstract}

\section{Keywords:}

agricultural extension; agriculture; public policy.

\begin{abstract}
Abstrak
Kajian ini bertujuan untuk mengungkap proses kebijakan dalam masyarakat digital. Perkembangan globalisasi yang tak bisa dinegasikan menyebabkan sektor pertanian di Indonesia menghadapi tantangan yang sama. Penyuluh pertanian dianggap sebagai bagian penting sebagai salah satu faktor yang menentukan dalam proses alih fungsi teknologi dan ilmu pengetahuan di Indonesia kepada petani. Studi kasus yang diambil adalah Kebijakan Penyuluh Pertanian Indonesia dan karakter penyuluh di Daerah Istimewa Yogyakarta. Kajian ini bermaksud melihat dua aspek berbeda yaitu (a) dinamika kebijakan pertanian terkait dengan tantangan masyarakat digital, dan (b) bagaimana penyuluh pertanian merespon kebijakan terkait globalisaasi dan perdagangan bebas. Data kualitatif diambil melalui interview mendalam dan FGD dengan komunitas penyuluh pertanian di Daerah Istimewa Yogyakarta sebagai data utama. Hasil penelitian menunjukkan bahwa peran dan karakter penyuluh pertanian tersebut berbeda di antara kabupaten. Meski demikian karakter penyuluh pada umumnya sama seperti karakter tenaga kerja pertanian yang cenderung menua dengan keterbatasan kemampuan penguasaan teknologi. Hasil kajian ini menjelaskan bagaimana kebijakan secara historis menjadikan entitas penyuluh pertanian Indonesia sekadar menjadi obyek pembangunan dan bukan menjadi subyek. Fenomena ini yang harus dihadapi dan menjadi tantangan dalam persoalan pertanian global saat ini.
\end{abstract}

\section{Kata Kunci:}

penyuluh pertanian (lapangan); sektor pertanian; kebijakan publik.

\footnotetext{
${ }^{1}$ Universitas Gadjah Mada

Email: riawantiwahyu@gmail.com

${ }^{2}$ Universitas Gadjah Mada
} 


\section{Introduction}

The dynamic of globalization has driven any nation to the changes of management in several sectors including agriculture and food policy. This study aimed to unwrap the dynamic of public administration process in a challenging digital society. Meanwhile the historical evidence explained that sone of the main achievement of Indonesia government is the productivity of food especially rice. Most of different regime tried to lower price of basic food in Indonesia to be moderately inexpensive. In this purpose, the government will do anything for the sake of cheap food at all cost. , including put all energy in the role of agriculture extension. This interest of government in fulfilling the need was practiced since Order Lama era until the era. In New Order, rice was considered as a very political commodity so that the food institution was always the source of political party interest (Timmer, 2004). According to Simatupang (1995) as reconfirmed by Lassa (2009), even the food policy in Indonesia was merely the practice of kleptocracy activity since Soeharto regime use Bulog as for the interest of individual and political purpose. $^{3}$

Facing the globalization, agriculture sector also has to cope with the same challenge to adjust with the global demand worldwide. In term of food global need, it is the public administration to provide the solution where the need of food is growing bigger and the worlds is considered getting smaller. Indonesia had faced problems in agriculture sector since the middle of 90'es when the productivity went declining. For the productivity reason, the role of agricultural extension is considered as one of the main factors in transferring technology and knowledge to the farmers to fulfill the productivity achievement

\footnotetext{
${ }^{3}$ Kleptocracy refers to the term according to Winters (2000) which means negative behavior of a government that pay attention only in their own interest by exploiting resources and inefficient political economy
}

A decade later government has to deal with the big problem of food import including rice as staple food. No wonder that after that era all of government regime put the food policy and agriculture productivity as one of the development priorities. In term of increasing the productivity, extension agents (Penyuluh Pertanian) play a prominent role in achieving higher productivity.

The study will focus on public administration process in term of challenging globalization and today's digital society. Some studies in developing countries reported that the digital agricultural extension method has increased the result effectively into 7 to 10 times over a classic method. One of the potential for applying such advanced method should meet the requirement of possessing sufficient agriculture sector and experiencing digital society Yogyakarta Province.

In the same time Indonesian agriculture sectors have problem in aging farmers and other agriculture actors, the emergency need for food supply should be fulfilled. Refer to this emergency needs, it is considered that the need of better agricultural productivity and the need of digital society should be in the same way to get the comprehensive policy and better solution.

Based on those problems, it seems that government face the two contradictions of entities: (a) the aging farmers with lower technology transfer and (b) the very demanding global society that require technology as one of the main information media. The paper will answer on how the government has dealt with the problem and how they put the every element to provide the policy.

\section{Literature Review}

\section{Public Policy in Digital Community}

Public administration was at a crossroad in term of either it should follow the public needs or follow the nation situation is the difficult path to take. If government has 
to provide what public need, they have to deal with the very advanced and extremely changing society. In the other hand, the extension work and atmosphere are different from the situation. The policy to make them meet in the same point will take long tough process to achieve.

The very same concern was studied by Farazmand (1999) about globalization and its implication for public administration. Both positive and negative consequences of globalization were discussed using the approach of political economy. One of negative consequences of globalization is Corruption and elite empowerment. Globalization pushes privatization as a part of structural-adjustment programs. Such corruption at the highest levels has already reached the point of national crisis. And later on, since Globalization as a process using a political economy view, this notion refers to globalization not as a phenomenon, but as a process - a continuing process of capital accumulation in modern capitalism that has been going on for centuries.

Thebiggest concern of publicadministration was that globalization will end the role of state. But since capitalism needs the state, and the state is not independent from capital; the elites of both work together in the globalization process because it serves both. For that reason, Farazmand argued that globalization does not end the state and public administration. There is a new global challenge that broadens public administration's scope of research, practice, and teaching. Public administration has just entered a new stage of human civilization, with a future that is both brightened and darkened by globalization and the hegemonic world order. We hope that prosperity for all will be the outcome (Farazmand, 1999: 509).

\section{Political Economy Approach}

Public policy should be able to be engaged with its public value. The literature review on extension policy did not emerge this aspect.
Research and study on extension agents were also reviewed as comparative study with other countries. The characters of Indonesian policy are shown in table 1.

Partly the research results in particular issues are simply. Firstly, The consequences of globalization in political economy approach. Secondly, positive consequences as continuity and persistent of the state. Negative consequences are thread to democracy and community and elite empowerment. Furthermore, according to the more recent study of Farazmand, converting possible counter hegemonic model that might alter or change the dominant world order (Farazmand, 1999).

Another study was organized by Farazmand (2004) and has shown that some of the most commonly known and often used concepts of governance or overnment during the last two decades or so are the following: good governance, intrepreneurial government, competitive government, and so on. A key haracteristic of all these concepts is a claim to rejecting the traditional forms of uthoritarian, bureaucratic government with unilateral decision making and implementation. These models or concepts of governance and government therefore pesent "new" ways of thinking, governing, and administration, with new philosophies nd new approaches that broaden citizen involvements and their feedbacks, and bring into the playing field the civil society and nongovernmental organizations.

The challenges faced by globalization are meeting basic human needs, limiting population growth, restricting consumption of nonrenewable resources, building a ense of world community, and negotiating mutually beneficial agreements mong nations. These global sustainable goals can be achieved only within an extended, intergenerational timeframe with a collaborative, enlightened, and owerful political leadership at the helm 
(Farazmand and Pinkowski, 2006).

In other hand Duane (2004) had the same research focus on the global capital and its implementation. Examination the individual roles of separationof powers were observed such as federalism, and bicameralism in mediating the welfare impacts of internationalization confrms theoretical expectations. Thise estimation of the interactions of separation of powers with liberalization and the three forms of capital ows produces two insignifcant coeffcients and two substantially tiny positive coeffcients. Finally estimation of the (eight) interactions between federalism and bicameralism on the one hand, and the four capital mobility variables on the other, produces eight negative and signifcant coeffcients. Thus, the dimension of decentralization, as conceptualized and measured here, is the most important aspect of the structure of policymaking authority for conditioning the impact of internationalization.

\section{Extension Policy and Novelty}

Shortly of the literature review shown that both implications are faced in this sector. This also provides the further question on how government has dealt with today's challenge to provide the solution. This was simply the novelty of the study. As comparison Rikin (2009) has reported that Agricultural extension officer in India tends to restrict contact only to the richer farmer.

Another research in Bangladesh was taken by $\mathrm{CABI}$ and found out the positive respond from the farmers group that enthusiasm of farmers was the main social capital to succeed the knowledge transfer. Most of farmers were challenged to be "on TV". Qualitative of extension method and multiple learning tools were used during the whole one year pilot project. The very effective and innovative program for Bangladesh was caused by the nation character. Bangladesh has experience and learned from Grameen Bank Microfinance and agricultural empowerment program (CABI, 2007).

The success in some less developed countries is confirmed with the recent study on extension agents. Global agriculture sector believe that the most important things in improving rural development are Agriculture Knowledge, Science and Technology. Also it is supported by an Implication of Policy Simulations (IAASTD, 2009: 354).

To contribute to the extension officer activity, Subejo (2004) has learned from the previous research in term of local autonomy. Decentralization era seems to the promising for Indonesian extension policy since thesteps would be shorter and would be able to accommodate local issues. Furthermore, empirical evidence has shown that extension problem existed in term of agricultural extension performance. Several issues on agricultural extension have been deeply studied as Agricultural Extension and Emerging Situation (Djuara P. Lubis). Some topic have been chosen as dissertation focus such as agriculture extension based on formal education (Sugeng Widodo, 2010); cyber extension as communication media (Retno Mulyandari, 2011) and the use of information for horticulture farmers (Dwi Hapasari, 2012)

\section{Research Methods}

The case study was taken on Indonesian agriculture policy in Yogyakarta Province to reveal two different aspects namely (a) agriculture policy relevancy to deal with nowadays digital challenge and (b) how the extension agents respond the policy in terms of globalization and international trade. The qualitative data was taken from in-depth interview and FGD with extension agents in Yogyakarta province were used for the research main data. The pre-research result has shown that the impact varied from different extension groups/districts.

Those prominent issues were then divided again into 5 research indicators to lead in obtaining data research, namely (1) 
the phenomena of overlapping regulation, (2) political affiliation and nepotism, (3) general food regulation, (3) government program in justifying any policy, (4) food institution transformation, and (5) local autonomy. Data triangulation was made to develop the deeper and comprehensive picture of the policy dynamic. Media literature and in-depth interview of policy-makers were used for primary data, and other data and information from statistic, regulation and other government legal document were collected for supporting data.

\section{Discussion}

\section{Public Administration at A Crossroad}

Indonesian public policy was at a crossroad. Either it should follow the public needs or follow the nation situation is the difficult path to take. If government has to provide what public need, they have to deal with the very advanced and extremely changing society. In the other hand, the extension work and atmosphere are different from the situation. The policy to make them meet in the same point will take long tough process to achieve.

As the biggest concern of public administration that globalization will end the role of state, it was capitalism that needs the state, and the state is not independent from capital; the elites of both work together in the globalization process because it serves both (Farazmand, 1999: 509).

\section{Historical Policy on Extension Agents}

This will explain how the process during older time is the main process when policies were formulated. During New order regime, extension agents are the extended hands of government. Related with political dynamics in Indonesia agriculture is important engine for economic development and agricultural extension was also developed (Lubis,
2013). Meanwhile, government itself is the representative of the regime. It is proven that extension agents are the part of political choice in increasing food. Other evidence showed that the existence of extensions agent and the institutions were merely the existence of agricultural inputs. Later on, in decentralization era in many districts, agricultural development (and agency) was abandoned.

Agricultural inputs were the main factor in increasing productivity. During the Green Revolution of 1960-1990, there were numbers of MNCs that provide the inputs for achieving self sufficiency food called Swasembada Pangan. The characters of extensions agents and mostly Indonesian agriculture sectors are mostly the aging labors and lower technology. But soon after the end of New Order, innovation should be introduced so that the main extension task will be well delivered.

During last decade some necessarily interesting programs were built and developed throughout Indonesia. But again, the disadvantage of condition still found as follow: (1) Inconsistency of extension institutions in both national and regional levels. This did not meet the requirement based on Law $\mathrm{Nbr}$. 16/ 2006 about Agriculture Extension System, (b) the lack of extensioon officers numbers based on Law Nbr 16 / 2006 and Ministry paper Nbr 72/2012, (c) insufficient inter-sector connection with extension agents. The Law of 16/2006 of Revitalization of Agricultural Extension mentioned to invite private sector and Non Government Organization (NGO) to get more involved. The law was that instead of finding the better solution, it comes to the fact providing more problems. Furthermore, it also challenged to advocating the utilization of ICT for agricultural development.

During this time (2006-2016) cyber extension is one of the communication media. But mostly effectively used only for horticulture farmers. The new paradigm was expected after reformation (Slamet Margono, 2003). The case 
Table 1.

Applications and advanced tools during 2012 to 2017 in increasing productivity of agricultural sector

\begin{tabular}{|c|c|c|c|c|}
\hline No & Title & Year & Owner & Information \\
\hline 1 & Petani $^{*}$ & 2016 & $\begin{array}{l}\text { One of the National } \\
\text { Program "Synergy Action } \\
\text { for the Economy". } \\
\text { It is an Android } \\
\text { application of UGM and } 8 \\
\text { Villages cooperation }\end{array}$ & $\begin{array}{l}\text { Is an information service related to agricultural } \\
\text { problem solving, place of sale of agricultural } \\
\text { equipment, information of agricultural training, } \\
\text { and online forum with fellow farmers all over } \\
\text { Indonesia }\end{array}$ \\
\hline 2 & $\begin{array}{l}\text { Aplikasi } \\
\text { TaniHub* }\end{array}$ & 2016 & $\begin{array}{l}\text { Tani Hub. } \\
\text { One of the National } \\
\text { Program "Synergy Action } \\
\text { for the Economy". }\end{array}$ & $\begin{array}{l}\text { This contains services on the distribution of } \\
\text { agricultural products and plantations from region } \\
\text { to city. }\end{array}$ \\
\hline 3 & $\begin{array}{l}\text { Aplikasi } \\
\text { LimaKilo* }^{*}\end{array}$ & 2016 & $\begin{array}{l}\text { PT. Limakilo Maju } \\
\text { Bersama. } \\
\text { One of the National } \\
\text { Program "Synergy Action } \\
\text { for the Economy". }\end{array}$ & $\begin{array}{l}\text { this application allows farmers to directly sell their } \\
\text { crops to consumers at competitive prices. }\end{array}$ \\
\hline 4 & $\begin{array}{l}\text { Aplikasi } \\
\text { Pantau Harga* }\end{array}$ & 2016 & $\begin{array}{l}\text { Code4Nation } \\
\text { One of the National } \\
\text { Program "Synergy Action } \\
\text { for the Economy". }\end{array}$ & $\begin{array}{l}\text { This is a place to bargain, and make buying and } \\
\text { selling between providers of raw materials with } \\
\text { farmers. This makes it easier to interact because there } \\
\text { is a database of price that becomes a reference. }\end{array}$ \\
\hline 5 & $\begin{array}{l}\text { Aplikasi } \\
\text { Nurbaya } \\
\text { Initiatives* }\end{array}$ & 2016 & $\begin{array}{l}\text { Nurbaya Initiatives. } \\
\text { One of the National } \\
\text { Program "Synergy Action } \\
\text { for the Economy". }\end{array}$ & $\begin{array}{l}\text { This service is provided for the economic players } \\
\text { of the people both farmers and SMEs to be able to } \\
\text { create a sales platform of the results. }\end{array}$ \\
\hline 6 & $\begin{array}{l}\text { Cybex } \\
\text { pertanian }\end{array}$ & 2010 & Ministry of Agriculture & $\begin{array}{l}\text { this Internet-based extension media is a tool } \\
\text { to facilitate the work of agricultural extension } \\
\text { workershttp://cybex.pertanian.go.id/ }\end{array}$ \\
\hline 7 & $\begin{array}{l}\text { SiHati } \\
\text { (Sistem } \\
\text { Informasi } \\
\text { Hargadan } \\
\text { Produksi } \\
\text { Komoditi) }\end{array}$ & 2015 & Bank Indonesia & $\begin{array}{l}\text { The site provides strategic commodity price } \\
\text { development information } \\
\text { In addition, it aims to suppress price speculation in } \\
\text { the market that has an impact on inflation }\end{array}$ \\
\hline 8 & Eragano & 2015 & $\begin{array}{l}\text { Founded by Stephanie } \\
\text { Jesselyn, a graduate of } \\
\text { the engineering faculty } \\
\text { of the Bandung Institute } \\
\text { of Technology (ITB), and } \\
\text { Aris Hendrawan, owner } \\
\text { of agricultural land in } \\
\text { Rancamaya, Bogor }\end{array}$ & $\begin{array}{l}\text { Provides several agricultural services at once, from } \\
\text { the sale of agricultural equipment and fertilizers, } \\
\text { the sale of crops, the wet land management system, } \\
\text { to lending to farmers. Eragano also created a media } \\
\text { portal so that farmers could find out information } \\
\text { related to agriculture. }\end{array}$ \\
\hline 9 & $\underline{\mathrm{iGrow}}$ & 2014 & $\begin{array}{l}\text { PT iGrow Resources } \\
\text { Indonesia }\end{array}$ & $\begin{array}{l}\text { users in this case who provide the funds, with } \\
\text { farmers, landowners, and buyers of agricultural } \\
\text { produce }\end{array}$ \\
\hline 10 & Karsa ** & 2016 & $\begin{array}{l}\text { Yudha Kartohadiprodjo } \\
\text { dan tim }\end{array}$ & $\begin{array}{l}\text { Applications that can provide agricultural } \\
\text { information to farmers, producers of agricultural } \\
\text { products, and government. With this application, } \\
\text { farmers can get information on how to grow } \\
\text { good crops. On the other hand, producers and } \\
\text { governments can also find out what the farmers } \\
\text { need, and monitor the prices of agricultural products } \\
\text { in the market. }\end{array}$ \\
\hline 11 & Crowde $* *$ & 2016 & $\begin{array}{l}\text { PT Crowd Membangun } \\
\text { Bangsa }\end{array}$ & $\begin{array}{l}\text { A crowd funding plattform that can be used to invest } \\
\text { in agriculture }\end{array}$ \\
\hline
\end{tabular}


connection from page 6

\begin{tabular}{|c|c|c|c|c|}
\hline 12 & Sikumis** & $\begin{array}{c}2016 \\
\text { (transformasi) }\end{array}$ & PT. SabasSinergi Indonesia & $\begin{array}{l}\text { Sikumis.com offers a variety of agricultural, } \\
\text { livestock, fishery and agri-SME products involving } \\
\text { traditional market traders http://www.sikumis. } \\
\underline{\text { com/ }}\end{array}$ \\
\hline 13 & $\begin{array}{l}\text { CI- } \\
\text { Agriculture }\end{array}$ & 2014 & PT Agri Tekno Kaya & $\begin{array}{l}\text { An agricultural land management solution based on } \\
\text { weather analysis, ground sensors, satellite imagery, } \\
\text { and drone use. They can give recommendations on } \\
\text { when to plant seeds, fertilize, add medicines }\end{array}$ \\
\hline 14 & $\begin{array}{l}\text { Habibi } \\
\text { garden }\end{array}$ & 2016 & $\begin{array}{l}\text { Dian PrayogiSusanto dan } \\
\text { tim }\end{array}$ & $\begin{array}{l}\text { Habibi Garden is startup that can provide real-time } \\
\text { data about soil conditions in a plantation. With the } \\
\text { data, the provision of nutrients can be more effective. } \\
\text { Habibi Garden also created an application that } \\
\text { allows you to see the development of plants from } \\
\text { smartphones. }\end{array}$ \\
\hline 15 & Lelanik *** & 2016 & $\begin{array}{l}\text { Participants of innovations } \\
\text { that Passed to Bootcamp } \\
\text { Stage Integrated } \\
\text { Broadband Village } \\
\text { Solutions }\end{array}$ & $\begin{array}{l}\text { A platform that allows farmers to be able to find out } \\
\text { the news of the market through mobile applications } \\
\text { and SMS. }\end{array}$ \\
\hline 16 & MyAgri *** & 2016 & $\begin{array}{l}\text { Participants of innovations } \\
\text { that Passed to Bootcamp } \\
\text { Stage Integrated } \\
\text { Broadband Village } \\
\text { Solutions }\end{array}$ & $\begin{array}{l}\text { This is a mobile app that can help farmers in gaining } \\
\text { knowledge that is important to them. Through this } \\
\text { application, you can learn about how to calculate } \\
\text { the appropriate amount of fertilizer, how to } \\
\text { recognize pests, to information about agricultural } \\
\text { machinery. }\end{array}$ \\
\hline 17 & Panen.id $* * *$ & 2016 & $\begin{array}{l}\text { Participants of innovations } \\
\text { that Passed to Bootcamp } \\
\text { Stage Integrated } \\
\text { Broadband Village } \\
\text { Solutions }\end{array}$ & $\begin{array}{l}\text { An app that can help you find farmers who sell } \\
\text { your crops around you. You can also buy their crops } \\
\text { directly through the application. }\end{array}$ \\
\hline 18 & $\begin{array}{l}\text { Silat (sistem } \\
\text { lelang hasil } \\
\text { tani) } * * *\end{array}$ & 2016 & $\begin{array}{l}\text { Participants of innovations } \\
\text { that Passed to Bootcamp } \\
\text { Stage Integrated } \\
\text { Broadband Village } \\
\text { Solutions }\end{array}$ & $\begin{array}{l}\text { A buying and selling platform for aquaculture } \\
\text { products. Thus, it is expected that farmers will get } \\
\text { a higher selling price than usual. }\end{array}$ \\
\hline
\end{tabular}

Note:

* https://id.techinasia.com/startup-pertanian-ekonomi-rakyat

** https://id.techinasia.com/kumpulan-emstartupem-dan-aplikasi-pertanian-di-indonesia

*** bagian dari 25 Inovasi yang Lolos keTahap Boot camp program Solusi Desa Broadband Terpadu (SDBT), https://id.techinasia.com/inovasi-bootcamp-solusi-desa-broadband-terpaduuntuk program solusi broadband terpadulihathttp://broadband-desa.go.id/

in Garut Disrict, West Java showed the evidence that education level influence the efficiency on knowledge transfer from agricultural extension to farmers.

When extension agents' role is mostly for increasing productivity only, This confirm the previous study that extensions agent is just one of productivity input instead of the efficient tool to educate farmers (Prabowo, 2003 in Lubis, 2009)). Since the productivity is the main goal of government, this also concludes that the formulation of policy were state-oriented. In term of agricultural extension, some big policies were made during the period. The process has shown that the formulation meet the theory of statecentered policy making process as followed: (a) policy elites with very limited numbers of policy makers (b) monopoly in step of policy making in providing public needs, and (c) lack of society participatory (Allison, 1999).

Robert Evenson describes agricultural extension efforts as following an awareness- 
Table 2.

The Characters of Policy of Indonesian Agriculture and Extension Agents

\begin{tabular}{|c|c|c|c|}
\hline No & Period & Name & Content \\
\hline 1 & $1920-1945$ & Pre Independence & $\begin{array}{l}\text { - Early Indonesian food sufficiency } \\
\text { - Different regime and change of institutions' name } \\
\text { - Colonial labor force for plantation }\end{array}$ \\
\hline 2 & $1945-1965$ & Post Independence & $\begin{array}{l}\text { - } \text { Severe food insufficiency } \\
\text { - Inflation of } 600 \% \\
\text { - } \quad \text { The initiation of Green Revolution }\end{array}$ \\
\hline 3 & $1965-1985$ & Green Revolution & $\begin{array}{l}\text { - Intensification and Agriculture inputs } \\
\text { - Corporations for Inputs } \\
\text { - Highly Production Increasing } \\
\text { - } \text { Food Self Sufficiency }\end{array}$ \\
\hline 4 & $1985-1988$ & Post Self Sufficiency & $\begin{array}{l}\text { - Land degradation of quality } \\
\text { - Early decreasing of productivity }\end{array}$ \\
\hline 5 & 1998 - recent & Reformation & $\begin{array}{l}\text { - Severe land quality problem } \\
\text { - Local Autonomy and Local food Sufficiency } \\
\text { - } \quad \text { Early technology applied }\end{array}$ \\
\hline
\end{tabular}

knowledge-adoption- productivity (AKAP) sequence [4]. Guiding a farmer through this progression to inculcate a particular technique is the aim of extension services. Agricultural extension in developing countries spans a history from the services provided to exportoriented crop estates during the colonial era to productivityfocused strategies, such as the World Bank's US\$3 billion Training and Visit (T\&V) system [5] that promoted Asia's Green Revolution in the 1970s. (Gandhi, et al, 2009).

Furthermore, the first effort as awareness insist that the agriculture extensuion to use and technology information to share the information to gain the awareness among the farmers group. Despite the problem of aging labor in agriculture sector, the extensions should be able to transfer the advanced technology. These applications of advanced technology are mostly made and provided by corporation, government and academic institution. During the last 5 years from 2012 to 2017 only, several applications were introduced to the agricultural sector to improve the farmers' knowledge and to increase productivity.

Among those advanced tools and applications there will be only few of them can be used and absorbed by the farmers as end users of this very technology. In fact, only
$11 \%$ of the farmers in Gunung Kidul district can access and familiar with IT and internet facilities. This simply shows how the extension agents respond the policy in terms of digitalized society and globalization.

\section{Research Data and Discussion}

Today's policy by government actually has no choice but to fulfill the public needs and demanding society. The digital society makes it possible to control government policy process and should work along the very dynamic and rapid moving of public. In term of extension world, the main role of extension agents is in transferring knowledge and play role as mediators between government and farmers. Thus, the system made by governments should meet the need of effectively transferring the information.

The main programs and government policy to face the globalization through technology information can be seen in some examples. Some applications were made by government and academic circle. In extension activity some applications have been applied such as SIMLUH, and SIMONEV. In other hand academic institution have developed system to make the process rapidly such as DUTY PLANT and PETANI application. Furthermore, the 
evidence taken from 4 districts and municipal in Yogyakarta Province has provided a various situation term of ICT and extension agents. In more advanced district and urban area (municipal), ICT is used for more than the last 5 years in transferring knowledge to farmers. But this is different with district more remote such as Gunung Kidul district and Kulon Progo.

\begin{abstract}
"Most of technology is provided in certain area. Even Yogyakarta is such as small region with limited agriculture products, the districts vary according to their own the climate character and geographical situation. For area like Gunung Kidul, only $11 \%$ of the farmers can access and familiar with IT and internet facilities (Interview with Puji Rahayu, August 26 $\left.6^{\text {th }} 2016\right)^{\prime \prime 4}$
\end{abstract}

The other interview and FGD were taken with farmer groups in Sleman District. ${ }^{5}$ The discussions were taken to reveal the the dynamic and relevance of agriculture policy to deal with nowadays society. The farmers have theor role in making and changing the implementation and regulation. The government compromised some of technical difficulties to ease the farmers problem when the farmers group think it is not a must to get their commodities certified.

Most of the farmers experience was from the Food Safety Certification. During the very long process, the groups were assisted by extension officer to make sure they are guided well enough. Along the process, the group admitted that the very big budget granted by local government was actually did not make

\footnotetext{
${ }^{4}$ Puji Rahayu, 31 years old woman, is an Extension Agent from Gunung Kidul District, Yogyakarta Province. Semin sub-district, where she works, is the most remote area in hilly location with the least fertile of soil condition and the lack of water. She mostly travels around approximately $50 \mathrm{~km}$ per day to reach the farmers who need her assistance.

${ }^{5}$ Taken August $16^{\text {th }} 2016$ with Salacca Farmers Group of "Kembang Mulyo" in Turi Sleman Yogyakarta
}

difference in commodities marketing. The exporters only need much more simple letter to be fulfilled. According to Mr. Sari, this was the very same problem among farmers group in Sleman District with same commodities.

\begin{abstract}
"One of main rules of extension agent is the role in food certification process. The certificate was obtained by the name of farmers group instead of individual one. For this reason, the group should be assisted by agricultural extension so that the process should meet the GAP aspect to fulfill the technical requirement. The main issue is the benefit of possessing the certification. Since the process is paid by government, the willing does not really come from the farmers. The process seemed to be the formal step only to get the certification from government. Even in government compromised some of technical difficulties to ease the farmers' problem, the farmers group think it is not a must to get their commodities certified. Furthermore the group can not find the difference between certified. Most of the time the exporter does not really ask for the certification pape"
\end{abstract}

Meanwhile, the group also thinks that government has also been very cooperative in term of regulation. In this case it also shows how the extension agents respond the policy in terms of digitalized society and globalization.

During the early certification process in the beginning of 2007, the farmer group thought that the requirement is too strict for them to deal with. Along the process they have to adjust with a very complicated recording, taking notes about every single detail of the process. In the later meeting the farmer was able to give a more simple way to make the process easier. Even so, the only aspiration was mostly from the chairman. ${ }^{6}$

${ }^{6}$ Pak Sari Saruji, lived in Sleman and manages his salacca plantation since 1986. 


\begin{abstract}
"Mostly Farmer's Group in Yogyakarta Province have the sub ordinary group for women farmers called KWT (Farmer Women Group). Even the decision was mostly made by the women in organization. It was still difficult to find out the real aspiration developed from the very root. The organization was dominated by few prominent persons who usually get involved with intern organization of village administration. Some KWT work efficiently and innovative such as the initiative program of "bank sampah" (trash bank) They collecting trash separately from village and salacca plantation." ${ }^{7}$
\end{abstract}

\section{Conclusion}

Result of this research were mainly the difference of focus and characters on policy including the different patterns policy through different regulation. Meanwhile, the main reason of extension work was merely that interest of government.

The policy of all five different periods were possessing the same indicators namely (a) extension agents as objects of development (b) in term of farmers, extension works more to transfer the government goal instead of what farmers need, and (c) incremental policy of agriculture extension. Explanation of research finally answered the hypotheses as followed: (1) government is the main actors and they are mostly the policy makers from food institution, (2) the actors came from different political party and bring about the different agenda to be supported with agriculture regulation, and (3) food institution determined the production based policy.

Two different aspects are namely (a) agriculture policy relevancy to deal with nowadays digital challenge and (b) how the extension agents respond the policy in terms of globalization and international trade. It

\footnotetext{
${ }^{7}$ FGD was taken in August 22 2016 with Women Farmers Group of "Muda Jaya" in Wonokerto Turi Sleman Yogyakarta.
}

concludes that the formulation of policy were state-oriented. In term of agricultural extension, some big policies were made during the period. The process has shown that the formulation meet the theory of state-centered policy making process as followed: (a) policy elites with very limited numbers of policy makers -no farmers organization get involved, even in Musrenbang (community discussion meeting), (b) monopoly in step of policy making in providing public needs-private extension is invited by the Law of Agriculture Extension, and (c) lack of society participatory -extension was part of the political agenda since New Order-.

1. The characters of extensions agents and mostly Indonesian agriculture sectors are mostly the aging labors and lower technology. This study will answer on how the public policy was historically put the entity of extension agents. The result will answer whether extension agents role are considered as the subject/object of development and how this phenomena will cope with recently global agriculture problem.

2. Evidence in Yogyakarta Province has provided a various situation term of ICT used by extension agent in transferring knowledge to farmers. The policy implementation should consider those different condition based on spatial in district level and local culture.

3. The law was that instead of finding the better solution, it comes to the fact providing more problems. In advocating the utilization of ICT for agricultural development (2006-2016) cyber extension is one of the communication media, but mostly effectively used only for horticulture farmers.

\section{References}

Allison, Graham, T. 1971. Essence of Decision: Explaining the Cuban Missile Crisis. Little, Brown and Company. Canada. 
Farazmand, A. (1999). “Globalization and Public Administration." Public Administration Review 59 (6): 509-522

Farazmand, A. (2004). Sound governance in the age of globalization: A conceptual framework. In A. Farazmand (Ed.), Sound governance: Policy and administration innovation. Westport, CT: Praeger.

Eklund, Niklas and Malin E. Wimelius. (2008). Globalization, europeanization, and administrative reform, Killian, Jerri and Niklas Eklund (eds). Handbook of administrative reform. An International Perspective. Boca Raton: yAuerbach Publications Taylor \& Francis Group

Gandhi, R., et al. (2009). “Digital Green: Participatory video and mediated instruction for agricultural extension." USC Annenberg School for Communication 5(1): 1-15.

Prizzia, Ross. (2007). Sustainable Development in an International Perspective, in Khi V. Thai, Dianne Rahm, Jerrell D. Coggburn [editors], Handbook of globalization and the environment. Boca Raton, London, and New York: CRC Press

Riawanti, Wahyu. (2015). Political Economy of Indonesian Food Policy: Case Study of Rent seeking on Rice Import in 1999-2009. Dissertation. Universitas Gadjah Mada.

Simatupang, P., I.W. Rusastra, M. Maulana. (2004). How to Supply Bottleneck in Agriculture Sector. Bogor: Center for Agrro
Socioeconomics Research and development (ICASERD).

Lassa, J.A., (2009). Memahami kebijakan pangan dan nutrisi: Studi kasus NTT. Journal of NTT Studies.

Swank, Duane (2004). Global Capital, Political Institutions, and Policy Change in Developed Welfare States. Cambridge, New York: Cambridge University Press.

Van Mele, P., A. Salahuddin and N.P. Magor (eds), (2005) Innovations in Rural Extension: Case Studies from Bangladesh. UK: CABI Publishing.

International Assessment of Agricultural Knowledge, Science and Technology for Development (IAASTD). (2009). Agriculture Crossroads Agriculture Crossroads: at a Global Report. Edited by Beverly D. McIntyre et al. Washington, DC: Island Press

Pardo, Theresa A., J. Ramon Gil-Garcia and Luis F. Luna-Reyes. (2008). Collaborative Governance and Cross-Boundary Information Sharing: Envisioning a Networked and IT-Enabled Public Administration. In Pardo, Theresa A., J. Ramon Gil-Garcia and Luis F. Luna-Reyes (Eds), Minnowbrook III Conference, Lake Placid, New York, September. (pp. 5-7).

Timmer, C. P. (2004). Food Security and Economic Growth: An Asian Perspective. In Heinz Memorial Lecture. Canberra, November 22 